\title{
The impact of modelling method selection on predicted extent and distribution of deep-sea benthic assemblages
}

\author{
Nils Piechaud ${ }^{1}$, Anna Downie ${ }^{2}$, Heather A. Stewart ${ }^{3}$ and Kerry L. Howell ${ }^{1}$ \\ ${ }^{1}$ Marine Biology and Ecology Research Centre, Marine Institute, Plymouth University, Plymouth, PL4 \\ 8AA, UK. \\ ${ }^{2}$ Centre for Environment Fisheries and Aquaculture Science, Pakefield Road, Lowestoft, NR33 0HT, \\ UK. \\ ${ }^{3}$ British Geological Survey, Murchison House, West Mains Road, Edinburgh, EH9 3LA, UK.
}

\begin{abstract}
Predictive modelling of deep-sea species and assemblages with multibeam acoustic datasets as input variables is now a key tool in the provision of maps upon which spatial planning and management of the marine environment can be based. However, with a multitude of methods available, advice is needed on the best methods for the task at hand. In this study, we predictively modelled the distribution and extent of three vulnerable marine ecosystems (VMEs) at the assemblage level ('Lophelia pertusa reef frameworks'; 'Stylasterids and lobose sponges'; and 'Xenophyophore fields') on the eastern flank of Rockall Bank, using three modelling methods: MaxEnt; RandomForests classification with multiple assemblages (gRF); and RandomForests classification with the presence/absence of a single VME (saRF). Performance metrics indicated that MaxEnt performed the best, but all models were considered valid. All three methods broadly agreed with regard to broad patterns in distribution. However, predicted extent presented a variation of up to $35 \%$ between the different methods, and clear differences in predicted distribution were observed. We conclude that the choice of method is likely to influence the results of predicted maps, potentially impacting political decisions about deep-sea VME conservation.
\end{abstract}

Key words: Cold-water corals, conservation, habitat mapping, model evaluation, vulnerable marine ecosystems

\section{Reference:}

Piechaud, N, Downie, A, STEWART, H A, and Howell, K L. 2015. The impact of modelling method selection on predicted extent and distribution of deep-sea benthic assemblages. Earth and Environmental Science Transactions of the Royal Society of Edinburgh. Vol. 105(4), 251-261. doi: $10.1017 / \mathrm{S} 1755691015000122$ 
Anthropogenic pressure on deep-sea habitats is growing, through fisheries and, specifically, through bottom trawling (Rooper et al. 2011; Norse et al. 2012; Puig et al. 2012), climate change, including rising deep ocean temperatures (Balmaseda et al. 2013) and ocean acidification (Form \& Riebesell 2011), and more recently, deep-sea mining (Colman Collins et al. 2013). Globally, there is increasing awareness of the need to develop and implement biodiversity conservation policy, to ensure appropriate and sustainable management of these ecosystems (Ban et al. 2013).

From an international perspective, the United Nations General Assembly resolution 61/105 (UN General Assembly 2003) requires the protection of vulnerable marine ecosystems (VMEs) from damaging fishing practices. From a regional perspective, Annex V of the OSPAR Convention ('On the Protection and Conservation of the Ecosystems and Biological Diversity of the Maritime Area') provides a list of Threatened and/or Declining Species and Habitats again for which conservation measures are required (OSPAR 2008). At a European level, the Marine Strategy Framework Directive (MSFD) requires an initial assessment of the current environmental status of European Union members' marine waters. Effective implementation of these policies requires a sound understanding of the extent and distribution of benthic biological assemblages as a starting point.

Maps have proved to be a useful method of summarising biological information concerning the seabed. There is now momentum towards the generalised mapping of the seafloor to provide information on which effective conservation policy can be based (Dolan et al. 2008; McBreen et al. 2011; Kenchington \& Hutchings 2012). However, large-scale mapping programmes have tended to focus on mapping the physical environment. While a vital first step, these physical maps provide only a coarse-level representation of the biology that is the subject of conservation efforts (Ward et al. 1999; Stevens \& Connolly 2004; Williams et al. 2009). They do not provide the comprehensive understanding of the extent and distribution of biological assemblages required by managers in order to make assessments on the potential impact of human use and decisions on appropriate management measures. As a result, and where data are available, maps of biological assemblages, often referred to as biotopes, are desirable.

Mapping at the level of biotopes or assemblages is a major problem in the deep sea, where sampling is expensive and logistically challenging, due to the deep sea's remoteness and depth, and the relatively poor ecological knowledge of the residing fauna. Recently, the use of species distribution modelling (SDM) has been applied to assemblages to map the distribution of deep-sea fauna over large areas (Howell et al. 2011; Rengstorf et al. 2013; Ross \& Howell 2013). In addition, smaller-scale site-based mapping of multiple assemblages has also applied predictive modelling techniques (Gonzalez-Mirelis \& Lindegarth 2012). Predictive modelling is a promising tool in this area, potentially reducing the cost of comprehensive field surveys by allowing the targeting of important areas, and filling data gaps for large areas of un-sampled seabed (Elith \& Leathwick 2009; Galparoso et al. 2009; Dambach \& Rodder 2011; Robinson et al. 2011).

Many different modelling methods are now available. Each has its strengths and weaknesses and the model has to be chosen carefully, considering the nature of the data available and the question or hypothesis under consideration. In practice, implementation difficulties, time consumption, output format or personal knowledge of its functioning also play a part in the choice of method. Elith \& Graham (2009) evaluated the most popular methods and stated that guidance in choosing an appropriate modelling method was incomplete and scattered across scientific literature, making 
objective choice difficult. There is evidence to suggest that the choice of modelling method may have a significant effect on both model performance and spatial prediction (Elith et al. 2006; Elith \& Leathwick 2009; Reiss et al. 2011; Downie et al. 2013). If maps produced using predictive modelling are to become established in the tool box of marine environmental managers, it is vital that the implications of model selection on model performance and, ultimately, spatial prediction are more widely understood.

This study focuses on creating three different high-resolution model maps for three benthic biological assemblages (biotopes) on the northeastern flank of Rockall Bank: the Lophelia pertusa (Linnaeus, 1758) reef (LpReef); the xenophyophore Syringammina fragilissima (Brady, 1883) aggregations (XeFi); and an assemblage characterised by dense aggregations of stylasterids and lobose sponges found on bedrock and mixed substrates (described by Long et al. 2010) (StyLSp). Each offers habitat complexity, enhancing three-dimensional (3D) structure and known to increase associated diversity (Buhl-Mortensen et al. 2010).

Lophelia pertusa is the dominant reef-building cold-water coral in the NE Atlantic, with the ability to form expansive reefs and carbonate mounds up to $300 \mathrm{~m}$ high. The framework formed by its skeleton increases habitat complexity, offering shelter for a highly diverse fauna (Roberts et al. 2006). Although the species may also be found as isolated colonies attached to patches of hard substrate (Wilson 1979; Mortensen \& BuhlMortensen 2004, 2005; Hovland 2005), the distribution of reefs is restricted to a much narrower set of environmental conditions (Howell et al. 2011). Here, we have focused on the reef habitat, which has an ecologically more important role in the deep sea.

Xenophyophore fields are found exclusively in the deep sea. Xenophyophores are singlecelled organisms, up to $25 \mathrm{~cm}$ in diameter. Syringammina fragilissima is one of the largest and most commonly observed species in the NE Atlantic, forming aggregations of up to 7-10 individuals per $\mathrm{m}^{2}$ (Tendal 1972, 1996; Gooday \& Tendal 2000; Roberts et al. 2000; Bett 2001). Sediments adjacent to large xenophyophore tests have been found to contain significantly more metazoan macro-fauna than surrounding sediments (Levin et al. 1986; Levin \& Thomas 1988), and the tests themselves can provide micro-habitats for small meiofaunal-sized metazoans (Gooday 1984) and foraminifera (Gooday \& Haynes 1983; Gooday 1991; Shires et al. 1994). Levin (1991, 1994) also suggests that xenophyophore tests may provide a structural habitat for epifauna. The stylasterids and lobose sponges assemblage is described by Long et al. (2010) as characterised by saddle oysters, brachiopods, Munida, serpulids, stylasterid corals, Cidaris cidaris (Linnaeus, 1758) and lobose sponges. This biotope has been described from Rockall Bank as associated with mixed substrate (a combination of different substrates types), boulders and bedrock, at temperatures of $9.2-9.7^{\circ} \mathrm{C}$ and at depths of 387-685 m. This assemblage fits the description of a VME, facing the same threats, and therefore is considered as such in this study.

All three habitats qualify as VMEs, whilst LpReef is also classed as a 'threatened and/or declining species and habitat' under the OSPAR Convention. The 3-D structure is fragile and can be broken by any physical actions, such as trawling, or weakened by poor calcification conditions, such as are occurring with increasing ocean acidification (Form \& Riebesell 2012). Additionally, the very slow growth rate of most of the species forming such 3-D habitats makes their recovery rate very slow (Althaus et al. 2009; Williams et al. 2010; Rooper et al. 2011). A better understanding of their distribution is critical to successful spatial management of these important habitats. The aim of this study was to investigate how consistently the distribution of habitats is 
described by the three different modelling approaches, with increasing ease of use: (i) prediction of the probability of presence, converted to an estimate of presence and absence using a probability threshold, applying Maximum Entropy modelling (MaxEnt, Phillips et al. 2006) separately for each habitat; (ii) prediction of presence or absence by Random Forest classification (Breiman 2001) separately for each habitat; and (iii) prediction of the most likely habitat by RandomForest. The impact of model choice on the predicted distribution of benthic assemblages was assessed using three VMEs as a case study, to highlight the implications of model plasticity for habitat mapping and environmental management.

\section{Method}

\subsection{Site description}

Rockall Bank is situated in the NE Atlantic Ocean, $40 \mathrm{~km}$ west of the UK mainland. It forms part of the larger Rockall Plateau, comprising Hatton Bank, Rockall Bank, George Bligh Bank and the intervening Hatton Basin (Fig. 1). The Rockall Bank itself is approximately $450 \mathrm{~km}$ long, running NE-SW, and $150 \mathrm{~km}$ wide at its widest point between the $1000 \mathrm{~m}$-depth contours. It ranges in depth from $0 \mathrm{~m}$ to P1500 $\mathrm{m}$. This study is focused on the eastern and northeastern flanks of the bank that fall away very steeply from $250 \mathrm{~m}$, descending into the Rockall Trough at 1000-1900 m depth.

\subsection{Survey}

The study area was surveyed during research cruises in 2005, 2009 and 2011 (Stewart et al. 2009; Jacobs et al. 2006; Long et al. 2010; Huvenne 2011). High-resolution multibeam echosounder data were acquired in 2005 on $S / V$ Kommander Jack, using an EM120 system (12 kHz; 191 beams); and in 2009 on M/V Franklin, using an EM710 system $(70-100 \mathrm{kHz} ; 400$ beams). Sound velocity measurements were performed at regular intervals to account for hydrology effects during all three surveys. Multibeam echosounder data were processed on board ship and onshore by OSAE Ltd. in 2005 and by Marin Mätteknik AB in 2009. Data were gridded at resolutions appropriate to the quality of the data (2005: $25 \mathrm{~m}$ grids; 2009: $20 \mathrm{~m}$ grids (East Rockall area C1 AD), with all other survey areas gridded at $15 \mathrm{~m}$ ). Minimum water depths encountered within the study area were $160 \mathrm{~m}$; maximum water depths were $1900 \mathrm{~m}$ (Fig. 1). As the modelling methods require all environmental data to have the same geographic bounds and cell size, all multibeam echo sounder datasets were regridded in ArcGIS to $25 \mathrm{~m}$ and merged to produce a single data layer, which was then used to produce subsequent derived layers.

A total of 19 transects, from $500 \mathrm{~m}$ to $1500 \mathrm{~m}$ long, were undertaken along the northern and eastern flanks of Rockall Bank to acquire video/still images. Seventeen transects were completed in 2009 using a drop frame camera system; two were achieved in 2011 using an ROV. Detailed technical specifications of the survey and camera systems are available in the source literature.

\subsection{Biotope data}

Fifteen distinct benthic assemblages were identified at the site as part of a separate study. Three of these assemblages are VMEs and were selected as the focus of this study. A total of 1029 records (the presence of an assemblage in a grid cell) were included in the biotope dataset (Table 1). At each sample location, the assemblage observed was assigned to one of the fifteen specified assemblages. A presence-absence 
dataset was extracted for each VME by assigning the observations of other assemblages as absences. Sample data were reduced to one data point per cell of topographic data. Cells where both presence and absence were recorded were assigned a presence.

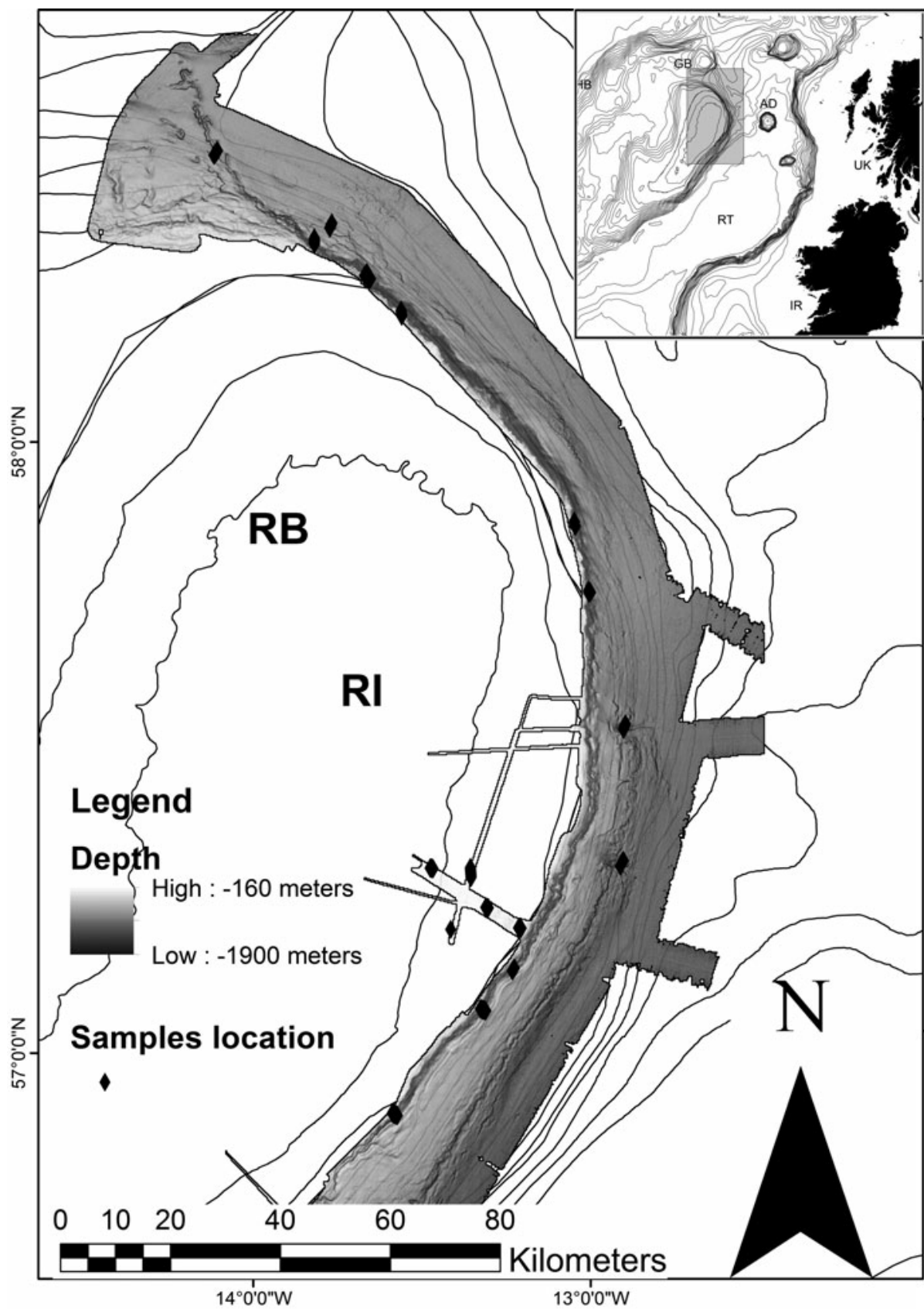

Figure 1 Full extent of the area covered by MBES survey. Black diamonds mark locations of video transects. Location abbreviations: AD 1/4 Anton Dohrn; GB 1/4 George Bligh Bank; HB 1/4 Hatton Bank; RB 1/4 Rockall Bank; RI 1/4 Rockall Island; RT 1/4 Rockall Trough. Bathymetry outside the study area is GEBCO and is displayed as $100 \mathrm{~m}$ isobaths to $2000 \mathrm{~m}$ depth, then at 500-m intervals. Map is projected in WGS 1984.

Table 1 Number of presences of each of the 15 assemblages described on Rockall Bank

\begin{tabular}{ll}
\hline Record number & Assemblage name \\
\hline 45 & Lophelia pertusa reef framework \\
158 & Stylasterids and lobose sponges on bedrock and mixed substrate \\
170 & Xenophyophore fields \\
656 & absences (other assemblages) \\
\hline
\end{tabular}




\subsection{Predictor variables}

Some of the factors that are suggested to influence strongly the distribution of deep-sea species include temperature and pressure (Tyler \& Young 1998), substrate (Howell et al. 2010), food supply (Ruhl \& Smith 2004), water mass structure (Miller et al. 2011), current speed and direction (Rice et al. 1990; White et al. 2005) and oxygen concentration (Rogers 2000). High-resolution data layers for these variables are not available for most of the deep sea, and where data layers are available they are usually derived from models subject to error. Multibeam bathymetry, on the other hand, provides true full-coverage, high-resolution data on seabed topography. It is relatively inexpensive to collect and a number of national mapping programmes are currently underway (MAREMAP (UK); MAREANO (Norway); Deep-Sea Coral Research and Technology Program (USA.); MESH-Atlantic (international)), thereby providing a vast dataset. Bathymetry and topographical variables derived from it, such as slope and rugosity, provide proxies for many other deep-sea variables, including temperature (where biogeography is taken into account), current speed, water mass structure, food availability and sediment type (Howell et al. 2002; Howell 2010).

Eight topographic predictor variables were included in this study, based on their expected significance as proxies for environmental factors that drive species distributions in the deep sea; namely, bathymetry, slope, rugosity, plan curvature (plan), profile curvature (prof), combined curvature (plan and profile combined (curv)), and bathymetric position index (BPI). Slope provides terrain gradient in degrees and serves as a proxy for the local hydrodynamic regime (Guinan et al. 2009). Rugosity acts as a measure of terrain 'roughness', or structural complexity, and also serves as a surrogate for substrate type (Rinehart et al. 2004; Dunn \& Halpin 2009). Profile curvature measures convexity/concavity of the terrain perpendicular to the direction of the maximum slope, whilst plan curvature is the convexity/concavity of the terrain parallel to the direction of the maximum slope and combined curvature regroups the two dimensions in the same index (Holmes et al. 2008). Along with slope, curvature also serves as a proxy for local-scale hydrology. Profile curvature affects the acceleration and deceleration of flow and, therefore, influences erosion and deposition; whilst plan curvature influences convergence and divergence of flow. BPI (equivalent to topographic position index) uses neighbourhood analysis to calculate the relative elevation of a cell, identifying topographic features such as ridges (positive BPI), valleys (negative BPI) and flat areas/constant slope (0) (Wright et al. 2005). BPI can be a proxy of various environmental features, such as exposure to current, current speed and orientation or sedimentation.

All topographic variables were derived from the $25 \mathrm{~m}$ bathymetry grid. In order to capture any possible scale-dependent relationships between predictor variable and habitat, all derived layers were calculated at $25 \mathrm{~m}, 100 \mathrm{~m}$ and $200 \mathrm{~m}$ raster cell size.

Slope (calculated as the maximum change in elevation over the distance between a cell and its eight neighbours), plan curvature, profile curvature and combined curvature were all calculated using the spatial analyst toolbox in ArcGIS 10.0, derived from a neighbourhood analysis.

Rugosity (calculated as the ratio of 3-D surface area to planar area) and BPIs were calculated using the Benthic Terrain Modeller extension (Wright et al. 2005). BPI was generated at fine (BPIfine) and broad (BPIbroad) scales, to provide separate layers defining small macrohabitats (sensu Greene et al. 1999) such as mounds, and large macrohabitats (sensu Greene et al. 1999) such as bank flank. BPIfine was generated with 
an inner radius of one cell and an outer radius of three cells (corresponding to scale factors of $75 \mathrm{~m}, 300 \mathrm{~m}$ and $600 \mathrm{~m}$, for the $25 \mathrm{~m}, 100 \mathrm{~m}$ and $200 \mathrm{~m}$ rasters, respectively); and BPIbroad was generated with an inner radius of one cell and an outer radius of five cells (scale factors of $125 \mathrm{~m}, 500 \mathrm{~m}$, and $1000 \mathrm{~m}$ ).

\subsection{Modelling approaches}

We selected two popular modelling methods, MaxEnt and RandomForest. These two methods are widely used for SDM, which makes their comparison valuable for future choices of methods in habitat mapping. Both methods have the advantage of being easily implemented, with a good capacity to cope with correlated variables (Cutler et al. 2007; Elith \& Graham (2009). RandomForest (RF) is a machine learning method by which a large number of classification or regression trees are built, and responses are predicted based on averages (regression) or by majority rules (classification) from all trees (Breiman 2001; Cutler et al. 2007). It has been widely used in ecological model ling (Elith et al. 2006; Elith \& Graham 2009; Hasan et al. 2012), possibly as a result of its ease of use (only two parameters to settle in the most commonly used RF implementation in $\mathrm{R}$ - the number of variables in the random subset at each node and the number of trees in the forest); its robustness to the inclusion of correlated variables (because only a subset of predictors is used to build each individual tree); and its flexibility of application to either discriminate between multiple categories or calculate the probability of occurrence of a single species or assemblage. RandomForest has the advantage of being able to produce one map from a single classification analysis. This results in a significant time saving during analysis. However, when used in this manner, its weakness is that the model is forced to assign each cell to only one biotope. This fails to reflect the potential occurrence of multiple assemblages in a cell, and also does not allow cells to remain unassigned representing potentially novel assemblages. We used RF in two ways, both based on the classification approach. A single classification model, referred to as the global RandomForest (gRF), was trained with input data consisting of samples classified into one of the 15 assemblages identified from the study site. The gRF model was used to predict to the whole study area, producing a single map where each raster cell is classified into the most probable of the fifteen assemblages. In the second approach, referred to as the single-assemblage RandomForest (saRF), a separate presence-absence classification model was built for each of the three VMEs. These models were used to predict the presence (as class) of each VME individually, resulting in three separate map products. RF models were fitted with the 'RandomForest' package version 4.6-7 in R (Liaw \& Wiener 2002). All models were run using the default values of random sample $\left(\mathrm{m}^{\text {try }}\right)$ of the predictors $\left(\mathrm{p}^{1 / 2}\right.$, where $\mathrm{p}$ is the total number of predictors), with 1000 trees grown for each model.

MaxEnt modelling is a modelling technique developed by Phillips et al. (2006), Phillips \& Dudík (2008) and Elith et al. (2011). It was chosen for this study because it has been found to be amongst the highest-performing modelling techniques for presence-only modelling (Elith et al. 2006). MaxEnt works with presence-only data (when the coordinates of observed presences only are available; i.e., it does not use absence data). It is only able to predict the distribution of one response variable (biotope) at once, and thus requires a model/map to be produced for each assemblage separately, resulting in significantly more analysis time. However, it has the advantage of allowing cells to contain multiple assemblages and remain unassigned. MaxEnt was used to construct probability of presence models for each of the three VMEs, resulting in the production of three individual map products, as with saRF. MaxEnt was run using the samples-with-data (SWD) approach, fitted on the presence records of each VME with background points composed of all the sampled locations. This 
method of 'target-group' background sampling controls for sample bias and improves predictive performance (Phillips \& Dudík 2008). Each model was fitted in $\mathrm{R}$ with the 'dismo' package version 0.8-11 (Hijmans et al. 2013) and the MaxEnt Java program version 3.3.3k (Phillips \& Dudík 2008). Regularisation settings were adjusted to reduce overfitting (Phillips \& Dudík 2008), resulting in a regularisation parameter of 2 for LpReef and 3 for XeFi and StylSp models. Each model was then projected onto the study area environmental layers, producing a logistic probability map with values between 0 (low probability) and 1 (high probability) for each VME. One master model was created for each listed habitat.

All models were built in R ( $\mathrm{R}$ Development Core Team 2011). Elith \& Leathwick (2009) highlighted the importance of some expert pre-selection of variables to ensure relevance; however, Elith et al. (2011) warn that stricter pre-selection is unlikely to improve the model. Therefore, no predictor variable pre-selection was undertaken and all models were constructed using the same set of predictor variables.

\subsection{Model evaluation}

Model performance was evaluated through cross-validation, by running each model on 100 randomly-generated splits into $75 \%$ training and $25 \%$ test data. Predictions of presence and absence on the test set from each run were extracted and average values for percentage of correctly classified (PCC), sensitivity and specificity were calculated over the 100 evaluations (Fielding \& Bell 1997; Manel et al. 1999). In the gRF predictions, the presence of any assemblage other than the one being evaluated was considered as an absence. The probability of presence output by MaxEnt was converted into binary presence-absence, applying the minimum receiver operating characteristic (ROC) curve distance optimal threshold (Liu et al. 2005). Each model was assessed using the 'presence/ absence' model evaluation library (Freeman 2007) in R.

\subsection{Variable importance evaluation}

MaxEnt and RF use different methods to weight the variables' relative importance in their predictions. Thus, the results of variable importance are not directly comparable across modelling methods. However, all three approaches rank the predictors according to their importance in determining assemblage distribution. This relative importance can be compared.

\subsection{Comparison of predicted distributions}

Predictions from full models for each of the three VMEs from MaxEnt and saRF, and the full model output from gRF, were transferred to ArcGIS as raster grids. The spatial predictions of each modelling method were compared by calculating the extent $\left(\mathrm{m}^{2}\right)$ and distribution of each VME within the study area, as predicted by each of the models. Extent was derived from the number of cells in the raster grid where the assemblage was present, given a grid cell is $25 \times 25 \mathrm{~m}\left(625 \mathrm{~m}^{2}\right)$. 
Table 2 Average and standard deviation of performance matrices (over 100 model runs) of each modelling method for the three VMEs (XeFi 1/4 xenophyophores fields; LpReef $1 / 4$ Lophelia Pertusa reef framework; StylSp 1/4 Stylasterids and globose sponges on mixed substrate). PCC 1/4 percentage correctly classified; .sd 1/4 standard deviation.

\begin{tabular}{lcccccc}
\hline & \multicolumn{5}{c}{ Maxent } \\
\cline { 2 - 7 } VME & PCC & PCC.sd & sensitivity & sensitivity.sd & specificity & specificity.sd \\
\hline XeFi & 0.94 & 0.01 & 0.93 & 0.03 & 0.94 & 0.01 \\
LpReef & 0.92 & 0.01 & 0.91 & 0.06 & 0.92 & 0.01 \\
StylSp & 0.94 & 0.01 & 0.92 & 0.04 & 0.94 & 0.01 \\
\hline & \multicolumn{7}{c}{ gensitivity } & sensitivity.sd & specificity & specificity.sd \\
\cline { 2 - 7 } VME & PCC & PCC.sd & sd & 0.96 & 0.01 \\
XeFi & 0.94 & 0.01 & 0.82 & 0.05 & 0.98 & 0.01 \\
LpReef & 0.96 & 0.01 & 0.82 & 0.11 & 0.96 & 0.01 \\
StylSp & 0.94 & 0.01 & & 0.05 & & \\
\hline & & & saRF & specificity & specificity.sd \\
VME & PCC & PCC.sd & sensitivity & sensitivity.sd & 0.98 & 0.01 \\
\hline XeFi & 0.97 & 0.01 & 0.92 & 0.05 & 0.99 & 0.01 \\
LpReef & 0.97 & 0.01 & 0.61 & 0.15 & 0.99 & 0.01 \\
StylSp & 0.97 & 0.01 & 0.92 & 0.04 & &
\end{tabular}

\section{Results}

\subsection{Model evaluation}

All models are considered valid, with MaxEnt being the best in terms of performance. For the three VMEs, all models achieved high PCC and specificity (all above 0.92), with fairly low standard deviation (<0.013) (Table 2). Similarity of PCC and specificity can be explained by the fact that the prevalence of presence data is low (Table 1), and so the PCC reflects mostly the ability of the model to predict absence, just as specificity does. All MaxEnt models had an excellent sensitivity (above 0.9). RF models for XeFi and StylSp had a good sensitivity ( $>0.818$ for gRF and $>0.916$ for saRF), but sensitivity for LpReef in both RF models was lower than for MaxEnt (0.49 in gRF; 0.61 in saRF), with higher standard deviation $(0.11$ and 0.15$)$. The poorer performance of the RF models for LpReef can be explained by the lower number of presence records (Table 1).

\subsection{Predictor variable importance}

All models predicted a distribution of the different assemblages driven mainly by depth, slope $(100 \mathrm{~m}$ and $200 \mathrm{~m}$ cell size) and rugosity (200 $\mathrm{m}$ cell size). Exceptionally, saRF for LpReef found that BPIbroad and BPIfine (200 $\mathrm{m}$ cell size) were the most important, followed by depth.

\subsection{VME distribution}

There is little overlap in the predicted distribution of these three assemblages. XeFi occupied the deepest part of the study area at the base of the slope (deeper than 1000 m) (Fig. 2). LpReef is predicted to be found between $600 \mathrm{~m}$ and $1000 \mathrm{~m}$ depth on the flank, and associated with raised topographic features. StylSp is predicted to occupy the upper part of the flank (between $300 \mathrm{~m}$ and $800 \mathrm{~m}$, but small patches may be found as deep as $1200 \mathrm{~m}$ ). 


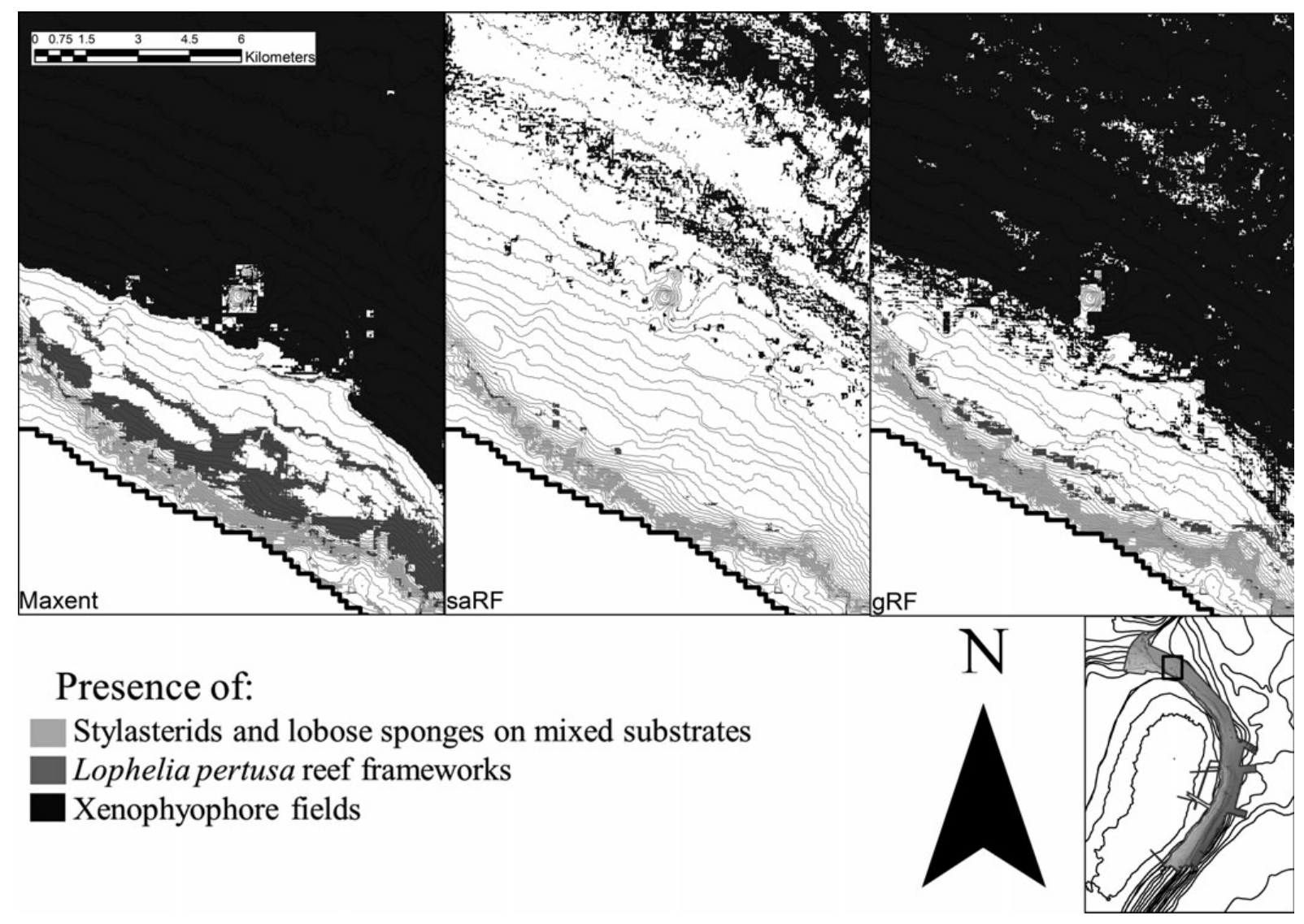

Figure 2 Distribution of the three Vulnerable Marine Ecosystems (XeFi 1/4 Xenophyophores fields; LpReef 1/4 Lophelia Pertusa reef framework; StylSp 1/4 stylasterids and globose sponges on mixed substrate) in subset of the survey area predicted by (from left to right) MaxEnt models, single assemblage RandomForest (saRF) models and global RandomForest models (gRF). Inset shows location of this survey area subset on Figure 1.

\subsection{Comparison of predicted distributions}

For all VMEs, MaxEnt models predict a larger extent than both RF models, but predicted extents for the global RF model and MaxEnt are more similar than those predicted from the saRF models (Table 3). In general, the saRF models predict more restricted distributions for all VMEs (Fig. 2).

All models predict XeFi to have the greatest extent. The gRF and MaxEnt models both predict large parts of the deepest portion of the survey area to be suitable for $\mathrm{XeFi}$, whereas the saRF predicts a patchy distribution only in the deepest parts of the study area.

MaxEnt predicts a greater extent of LpReef than StylSp, whereas both RF models predict the opposite (Table 3). The most striking difference in predictions of extent between models occurs for LpReef, where the MaxEnt predicted extent is 154 times larger than the saRF predictions. MaxEnt predicts the presence of LpReef in a wide band along the slope. The gRF model predicts a similar but more restricted distribution for LpReef, whereas the saRF model predicts LpReef to have a very patchy distribution in only the shallowest areas predicted by the other two models.

For StylSp, gRF predicts a slightly deeper distribution than the other two models, their presence extending on top of the crests, and MaxEnt predicts a distribution which extends onto shallower areas on the top of the slope. 
Table 3 Extent of all three VMEs as predicted by the three modelling approaches (XeFi 1/4 Xenophyophores fields; LpReef 1/4 Lophelia Pertusa reef framework; StylSp 1/4 Stylasterids and globose sponges on mixed substrate).

\begin{tabular}{|c|c|c|c|c|c|c|}
\hline \multirow[b]{2}{*}{ VME } & \multirow[b]{2}{*}{$\mathrm{Km}^{2}$} & \multirow{2}{*}{$\begin{array}{l}\text { Maxent } \\
\% \text { total surface }\end{array}$} & \multirow[b]{2}{*}{$\mathrm{Km}^{2}$} & \multirow{2}{*}{$\begin{array}{l}\text { global RF } \\
\% \text { total surface }\end{array}$} & \multirow[b]{2}{*}{$\mathrm{Km}^{2}$} & \multirow{2}{*}{$\begin{array}{l}\text { single RF } \\
\% \text { total surface }\end{array}$} \\
\hline & & & & & & \\
\hline $\mathrm{XeFi}$ & 3714.57 & 62.66 & 3686.97 & 62.19 & 2552.61 & 43.06 \\
\hline LpReef & 313.66 & 5.29 & 58.43 & 0.99 & 1.80 & 0.03 \\
\hline StylSp & 185.36 & 3.13 & 167.11 & 2.82 & 113.84 & 1.92 \\
\hline
\end{tabular}

\section{Discussion}

In this study, we have shown that the distributions of VMEs can be successfully modelled and the predicted distributions concur with what is previously known about their ecology and distribution. Although all of the modelling methods performed well in cross-validation, the selection of method was found to have a considerable effect on the extent of the predicted distribution. The discrepancy between model predictions has implications on their use in management applications, and care should be taken to validate models adequately and establish their spatial error margins.

\subsection{Model performance}

All three methods were successful at predicting the extent and distribution of the three targeted VMEs on northeast Rockall Bank. However, in comparison, the MaxEnt models performed best for all three VMEs, a finding consistent with previous model comparisons that found MaxEnt was the most efficient method for SDM (Elith et al. 2006; Elith \& Graham 2009; Reiss et al. 2011). The better overall performance of MaxEnt in this study is most likely a result of the low prevalence in the dataset, and the questionable reliability of absence data. The limited number of presence records (only 45 presence records for LpReef ) is probably responsible for the lower performance of RF models to predict this VME, as MaxEnt is known to deal better with small numbers of presence records (Wisz et al. 2008). The quality and reliability of absence data have been proved to be influential on the model performances (Smith et al. 2013). These authors emphasised that high-quality absence data were needed to assess SDMs quality, but also recognised that these data were generally difficult, if not impossible, to acquire. This statement is particularly true in the deep sea, given the significant investment in time and money required to collect a dataset.

\subsection{Predicted distribution of the VMEs across northeast Rockall Bank}

All three models agree to structure the distribution of the three VMEs on Rockall Bank in depth bands, with each one occupying a specific region on the flank of Rockall Bank. The areas where our models predict the presence of the three VMEs are consistent with current understanding of the distribution of these habitats.

Xenophyophore fields have been observed at depths of $860-1830 \mathrm{~m}$, although most records are from around $1000 \mathrm{~m}$ water depth (Hughes \& Gooday 2004). They are found on sandy silts and fine grained oozes; often in areas with enhanced organic carbon fluxes, such as beneath highly-productive surface waters, on sloped topography or near topographic features such as caldera walls, basalt outcrops, or on the sides of sediment mounds and small ridges (Tendal 1972, 1979; Levin \& Thomas 1988; Levin \& Gooday 1992; Hughes \& Gooday 2004). In this present study, XeFi was found below $1000 \mathrm{~m}$ water depth at the base of the flank of Rockall Bank, suggesting a potential association with the bank structure, likely to be a result of favourable oceanographic 
conditions associated with mixing or deflection caused by the bank structure. Xenophyophore aggregations have also been observed associated with the base of the neighbouring Anton Dohrn Seamount (Davies 2012) and the Darwin Mounds area of the continental slope (Bett et al. 2001). Ross \& Howell's (2013) recent broadscale model suggested Xenophyophore aggregations may be common to the base of many raised topographic features in the region, including the continental slope. The lower limit of the predicted distribution for Xenophyopores in this study has a high uncertainty associated with it, due to limited sampling in the deepest part of Rockall Bank, meaning the data are not fully representative of the entire niche occupied by this assemblage.

Lophelia pertusa reefs form under a specific set of environmental conditions. The largest reefs are known to occur in depths of 500-1200 m, at temperatures of $4-12^{\circ} \mathrm{C}$ (Frederiksen et al. 1992; Roberts et al. 2006; Wheeler et al. 2007). Factors driving reef formation are poorly understood, but are likely to be an interplay between local hydrography and sedimentary dynamics (Thiem et al. 2006; Howell et al. 2011), with most reefs being found on topographic highs and slopes (Strømgren 1971; Genin et al. 1986; Frederiksen et al. 1992; Davies et al. 2008), associated with features such as ridges (Sula Ridge), escarpments (Pelagia Mounds, Hatton Bank) and channels (Hovland Mounds) (Wheeler et al. 2007, Howell et al. 2011), and in areas of strong currents and high productivity (Mortensen et al. 2001; White et al. 2005; Thiem et al. 2006; Kiriakoulakis et al. 2007; Davies et al. 2008). In this present study, MaxEnt and gRF both predict a patchy, but more or less continuous, band of LpReef at mid-slope depths $(600-1000 \mathrm{~m})$, whereas saRF predicts a very patchy, more restricted and slightly shallower (400-1000 m) distribution (Fig. 2). Although sensitivity achieved by MaxEnt is higher, a continuous band of cold-water coral reefs running along the slope of Rockall Bank is unlikely. All models predict presence on areas of steep topography, with probability of occurrence increasing on slopes with a steepness of $>10 \%$. Presence also appears to be associated with troughs or peaks (high positive and/or negative BPI), as suggested by previous studies. These areas are where exposure to currents is highest. However, the small number of presence records for this biotope should lead to a careful interpretation of the results, and additional samples could be needed in order to improve RF models performances.

The Stylasterids and globose sponges on mixed substrates assemblage has only recently been described from Rockall Bank, based on the data used for this study (Long et al. 2010). In this study, it is predicted to occupy the upper part of the slope between $400 \mathrm{~m}$ and $700 \mathrm{~m}$ depth and the assemblage seems to prefer slopes steeper than 15-20\%. MaxEnt and saRF predict a distribution in the same depth band, although the MaxEnt model predicts a larger extent, whilst gRF predicts a slightly deeper distribution range stretching onto the tops of the ridges.

\subsection{Differences in predicted extent}

Although all three models performed similarly well, the final predictive maps produced by these models displayed differences in the extent and distribution of the three VMEs. The model validation results are all indicative of a valid model; yet, the final maps presented up to 30-35\% variation in the predicted extent of a VME, as well as clear differences in distributions (Fig. 2). These were mainly shifts in depth range, or presence on more or less vertical features. Previous authors have also observed differences in spatial predictions when comparing several modelling methods (Ready et al. 2010; Reiss et al. 2011; Downie et al. 2013). However, previous studies have 
found MaxEnt models to be restrictive in predictions, concentrating presence prediction around recorded presence points (Bentlage et al. 2009; Poulos et al. 2012; Downie et al. 2013). In this present study, we observed the contrary, with MaxEnt predicting the largest extent for all three VMEs (Table 3). The apparent difference in MaxEnt's prediction of restricted vs extensive distribution in our study is likely a result of the use of the pseudo-absence records as background in the "samples with data" approach to MaxEnt modelling taken, rather than allowing the use of random sampling across the study area.

\subsection{Implications on using models in management}

The observations in this study highlight the variability of the predictions across modelling methods. Even when a single model appears to perform well, when measured against validation statistics, and may be considered valid for use by managers, the predictions resulting from the model are subject to additional spatial error. This small but important point, illustrating apparently equally good model performance yet clear differences in spatial predictions, highlights the limits of SDM as a tool for conservation planning. It is a relatively straightforward process to produce a map, sparing the cost and effort of extensive field sampling. Basing management decisions on these maps is, thus, tempting and possibly inevitable, but we urge caution and recommend that predicted maps are best used as a starting point for targeting future surveys. If maps are to be used in the decision-making process, independent validation of the maps is critical to the full understanding of model performance (Elith et al. 2006). The good performance of the models in this study is encouraging, but it is at least partly a result of the evaluation procedure being based on random subsampling from the full dataset, as the lack of true independence between testing and training data sets, as well as spatial sorting bias, is known to artificially inflate model performances (Veloz 2009; Hijmans 2012). However, the good cross-validation results demonstrate the stability of the models over this dataset.

In this present study, the extent and distribution of the three studied VMEs varied depending on the modelling method used. The information about where multiple models predictions differ is useful and can be used to illustrate spatial uncertainty in predictions, highlighting to users the error potential of predicted maps. Similarly, information about where multiple models predictions agree may be used to identify possible core areas (central to a species distribution), although the effectiveness of this approach would have to be tested. Downie et al. (2013) suggest the use of an 'ensemble model' approach to mapping, combining the outputs of several models. However, other authors have found that whilst ensemble models can be of use, they do not necessarily improve predictions (Marmion et al. 2009; Grenouillet et al. 2011; Stohlgren et al. 2010). More research is needed in this area.

Whilst we recommend caution in the use of predictively modelled maps for management purposes, faced with the challenge of implementing conservation policy in vast areas of deep sea and High Seas, decisions are currently being taken based on 'best available data'. To date, decisions regarding the management of fisheries to protect VMEs have been taken on the basis of maps produced using point data, which may itself date back decades to more than 100 years ago (Aish et al. 2008; Auster et al. 2013). This essentially restricts conservation efforts to areas that have been sampled, hampering progress in sustainable management of the deep sea and High Seas. Thus, while predictively modelled maps have clear limitations, they do provide a scientifically robust and repeatable means of estimating extent and distribution of species and 
assemblages, and thus represent 'best available data'. We therefore advocate their use in marine management. However, it is important that environmental managers consider SDM predictions as the most probable distribution of the assemblage studied, given the available data, rather than a definitive picture of the reality. End users must always keep in mind that important aspects of this distribution might not have been caught by the sampling design. In addition, a good predictive model represents the potential range of a species (and in this case biotope), rather than the realised distribution (Downie et al. 2013) and, thus, estimates of extent based on models must also be treated with caution.

\section{Acknowledgements}

The authors would like to acknowledge with thanks the scientists, officers and crew of $R V$ Kommandor Jack and MV Franklin associated with the collection of data used in this study, including the most recent (JC060, PSO Veerle Huvenne of NOC, Southampton); J. Davies, C. Jacobs and N. Golding; R. Ross; the staff at Geotek and Marin Matteknik AB; the wider Mapping the Deep and MAREMAP project partners; and the Marine Biological Association of the United Kingdom. HAS publishes with permission of the Director, British Geological Survey (Natural Environment Research Council). 


\section{References}

Aish, A. et al. 2008. Report of the ICES-NAFO Joint Working Group on Deep Water Ecology (WGDEC). Copenhagen, Denmark: Interna- tional Council for the Exploration of the Sea. 124 pp.

Althaus, F., Williams, A., Schlacher, T. A., Kloser, R. J., Green, M. A., Barker, B. A., Bax, N. J., Brodie, P. \& SchlacherHoenlinger,

M. A. 2009. Impacts of bottom trawling on deep-coral ecosystems of seamounts are long-lasting. Marine Ecology Progress Series 397,279-94.

Auster, P. et al. 2013. Report of the ICES\ NAFO Joint Working Group on Deep-water Ecology (WGDEC) (11-15 March 2013, Floedevigen, Norway). Copenhagen, Denmark: International Council for the Exploration of the Sea. $95 \mathrm{pp}$.

Balmaseda, M. A., Trenberth, K. E. \& Kä llén, E. 2013. Distinctive climate signals in reanalysis of global ocean heat content. Geo- physical Research Letters 40, 1-6.

Ban, N. C. Ban, N. C., Bax, N. J., Gjerde, K. M., Devillers, R., Dunn, D. C., Dunstan, P. K., Hobday, A., Maxwell, S. M., Kaplan, D. M., Pressey, R. L., Ardron, J. A., Game, E. T. \& Halpin, P. N. 2013. Systematic conservation planning: A better recipe for managing the high seas for biodiversity conservation and sustainable use. Conservation Letters 7, 4154.

Bentlage, B., Peterson, A. T. \& Cartwright, P. 2009. Inferring distribu- tions of chirodropid box-jellyfishes (Cnidaria: Cubozoa) in geo- graphic and ecological space using ecological niche modeling. Marine Ecology Progress Series 384, 121-33.

Bett, B. J. 2001. UK-Atlantic margin environmental survey: introduc- tion and overview of bathyal ecology. Continental Shelf Research 21, 917-56.

Bett, B., Billett, D. Masson, D. \& Tyler, P. 2001. RRS Discovery Cruise 248. A multidisciplinary study of the environment and ecology of deep-water coral ecosystems and associated seabed facies and features (The Darwin Mounds, Porcupine Bank and Porcupine Seabight). Southampton Oceanography Centre Cruise Re- port 36. Southampton, UK: Southampton Oceanography Centre. 108 pp.

Brady, H. B. 1883. Note on Syringammina, a new type of arenaceous Rhizopoda. Proceedings of the Royal Society of London 35, 155- 61

Breiman, L. 2001. Random forests. Machine learning 45, 5-32.

Buhl-Mortensen, L., Vanreusel, A., Gooday, A. J., Levin, L. A., Priede, I. G., Buhl-Mortensen, P., Gheerardyn, H., King, N. J.

\& Raes, M. 2010. Biological structures as a source of habitat heterogeneity and biodiversity on the deep ocean margins. Marine Ecology31,21-50.

Colman Collins, P., Kennedy, B., Copley, J., Boschen, R., Fleming, N., Forde, J., Ju, S-J., Lindsay, D., Marsh, L., Nye, V., Patterson, A., Watanabe, H., Yamamoto, H., Carlsson, J. \& Thaler, A. D. 2013. VentBase: Developing a consensus among stakeholders in the deep-sea regarding environmental impact assessment for deep-sea mining - A workshop report. Marine Policy 42, 334-36.

Cutler, D. R., Edwards, T. C., Beard, K. H., Cutler, A., Hess, K. T., Gibson, J. C. \& Lawler, J. J. 2007. Random forests for classifica- tion in ecology. Ecology 88(11), 2783-92.

Dambach, J. \& Rodder, D. 2011. Applications and future challenges in marine species distribution modeling. Aquatic Conservation- Marine and Freshwater Ecosystems 21,92-100.

Davies, A. J., Wisshak, M., Orr, J. C. \& Roberts, J. M. 2008. Predict- ing suitable habitat for the cold-water coral Lophelia pertusa (Scleractinia). Deep-Sea Research Part I: Oceanographic Research Papers 55, 1048-62.

Davies, J. S. 2012. Mapping Deep-Sea Features in UK Waters for Use in Marine Protected Area Network Design. PhD Thesis, University of Plymouth, UK. 347 pp.

Dolan, M. F. J., Grehan, A. J., Guinan, J. C. \& Brown, C. 2008 Modelling the distribution of cold-water corals in relation to bathymetric variables: adding spatial contact to deep-sea video. Deep Sea Research Part 1: Oceanographic Research Papers 55(11), 1564-79.

Downie, A. L., von Numers, M. \& Bostrom, C. 2013. Influence of model selection on the predicted distribution of the seagrass Zostera marina. Estuarine Coastal and Shelf Science 121, 8-19.

Dunn, D. C. \& Halpin, P. N. 2009. Rugosity-based regional modeling of hard-bottom habitat. Marine Ecology Progress Series 377, 1-11.

Elith, J., Graham, C. H., Anderson, R. P., Dudík, M., Ferrier, S., Guisan, A., Hijmans, R. J., Huettmann, F., Leathwick, J. R. Lehmann, A., Li, J., Lohmann, L. G., Loiselle, B. A., Manion, G., Moritz, C., Nakamura, M., Nakazawa, Y., Overton, J. McQ. M., Peterson, A. T., Phillips, S. J., Richardson, K., ScachettiPereira, R., Schapire, R. E., Soberón, J., Williams, S., Wisz, M S. \& Zimmermann, N. E.. 2006. Novel methods improve predic- tion of species' distributions from occurrence data. Ecography 29, 129-51.

Elith, J., Phillips, S. J., Hastie, T., Dudík, M., Chee, Y. E. \& Yates, C. J. 2011. A statistical explanation of MaxEnt for ecologists. Diversity and Distributions 17(1), 43-57.

Elith, J. \& Graham, C. H. 2009. Do they? How do they? WHY do they differ? On finding reasons for differing performances of species distribution models. Ecography 32, 66-77.

Elith, J. \& Leathwick, J. R. 2009. Species Distribution Models: Ecological Explanation and Prediction Across Space and Time. Annual Review of Ecology Evolution and Systematics 40, 677-97.

Fielding, A. H. \& Bell, J. F. 1997. A review of methods for the assessment of prediction errors in conservation presence/absence models. Environmental Conservation 24(1), 38-49.

Form, A. U. \& Riebesell, U. 2012. Acclimation to ocean acidification during long-term $\mathrm{CO}_{2}$ exposure in the cold-water coral Lophelia pertusa. Global Change Biology 18, 843-53.

Frederiksen, R., Jensen, A. \& Westerberg, H. 1992. The distribution of the scleractinian coral Lophelia pertusa around the Faroe Islands and the relation to internal tidal mixing. Sarsia 77, 15771.

Freeman, E. 2007. PresenceAbsence: An R Package for PresenceAbsence Model Evaluation. Ogden, Utah: USDA Forest Service, Rocky Mountain Research Station.

Galparsoro, I., Borja, A., Bald, J., Liria, P. \& Chust, G. 2009. Predicting suitable habitat for the European lobster (Homarus gammarus) on the Basque continental shelf (Bay of Biscay), using EcologicalNiche Factor Analysis. Ecological Modelling 220, 556-67.

Genin, A., Dayton, P. K., Lonsdale, P. F. \& Spiess, F. N. 1986. Corals on seamount peaks provide evidence of current acceleration over deep-sea topography. Nature 322, 59-61.

Gonzalez-Mirelis, G. \& Lindegarth, M. 2012. Predicting the distribution of out-of-reach biotopes with decision trees in a Swedish marine protected area. Ecological Applications 22, 2248-64.

Gooday, A. J. 1984. Records of deep-sea rhizopod tests inhabited by metazoans in the North-East Atlantic. Sarsia 69, 45-53

Gooday, A. J. 1991. Xenophyophores (Protista, Rhizopoda) in BoxCore Samples from the Abyssal Northeast Atlantic-Ocean (Biotrans Area) - their Taxonomy, Morphology, and Ecology. Journal of Foraminiferal Research 21, 197-212.

Gooday, A. J. \& Haynes, J. R. 1983. Abyssal forminifers, including two genera, encrusting the interior of Bathysiphon rusticus tubes. Deep Sea Research 30, 591-614.

Gooday, A. J. \& Tendal, O. S. 2000. Class Xenophyophorea Schulze, 1904. In Lee, J. J., Leedale, G. F. \& Bradbury, P. (eds) The Illus trated Guide to the Protozoa, 2nd Edition, 1086-97. Lawrence, Kansas: Allen Press Inc., for the Society of Protozoologists. 1475 pp.

Greene, H. G., Yoklavich, M. M., Starr, R. M., O’Connell, V. M Wakefield, W. W., Sillivan, D. E., McRea, J. E. Jr. \& Cailliet, G. M. 1999. A classification scheme for deep seafloor habitats. Oceanologica Acta 22(6), 663-78.

Grenouillet, G., Buisson, L., Casajus, N. \& Lek, S. 2011. Ensemble modelling of species distribution: the effects of geographical and environmental ranges. Ecography 34, 9-17.

Guinan, J., Grehan, A. J., Dolan, M. F. J. \& Brown, C. 2009. Quantifying relationships between video observations of cold-water coral cover and seafloor features in Rockall Trough, west of Ireland. Marine Ecology Progress Series 375, 125-38.

Hasan, R. C., Ierodiaconou, D. \& Monk, J. 2012. Evaluation of Four Supervised Learning Methods for Benthic Habitat Mapping Using Backscatter from Multi-Beam Sonar. Remote Sensing 4, 3427-43.

Hijmans, R. J. 2012. Cross-validation of species distribution models: removing spatial sorting bias and calibration with a null model Ecology 93, 679-88.

Hijmans, R. J., Phillips, S., Leathwick, J., Elith, J. \& Hijmans, M. R. J. 2013. dismo: Species distribution modelling. (R package version 0.9-3 ed.)

Holmes, K. W., Van Niel, K. P., Radford, B., Kendrick, G. A. \& Grove, S. L. 2008. Modelling distribution of marine benthos from hydroacoustics and underwater video. Continental Shelf Research 28, 1800-10.

Hovland, M. 2005. Pockmark-associated coral reefs at the Kristin field off Mid-Norway. In A. Freiwald, A. \& J. M. Roberts, J. M (eds) Cold-water Corals and Ecosystems, 623-32. Berlin: SpringerVerlag.

Howell, K. L. 2010. A benthic classification system to aid in the implementation of marine protected area networks in the deep/ high seas of the NE Atlantic. Biological Conservation 143, 104156

Howell, K. L., Billett, D. S. \& Tyler, P. A. 2002. Depth-related distribution and abundance of seastars (Echinodermata: Asteroidea) in the Porcupine Seabight and Porcupine Abyssal Plain, NE Atlantic. Deep-Sea Research Part I: Oceanographic Research Papers 49, 1901-20.

Howell, K., Davies, J. \& Narayanaswamy, B. 2010. Identifying deep- 
sea megafaunal epibenthic assemblages for use in habitat mapping and marine protected area network design. Journal of the Marine Biological Association of the United Kingdom 90, 3368.

Howell, K. L., Holt, R., Endrino, I. P. \& Stewart, H. 2011. When the species is also a habitat: Comparing the predictively modelled distributions of Lophelia pertusa and the reef habitat it forms. Biological Conservation 144, 2656-65.

Hughes, J. A. \& Gooday, A. J. 2004. Associations between living benthic foraminifera and dead tests of Syringammina fragilissima (Xenophyophorea) in the Darwin Mounds region (NE Atlantic). Deep-Sea Research Part I: Oceanographic Research Papers 51, 1741-58.

Huvenne, V. A. I. 2011. RRS James Cook Cruise 60, 09 May-12 June 2011. Benthic habitats and the impact of human activities in Rockall Trough, on Rockall Bank and in Hatton Basin. National Oceanography Centre Southampton Research \& Consultancy Report

04. Southampton, UK: National Oceanography Centre, Southampton. 133 pp.

Jacobs, C. et al. 2006. SV Kommandor Jack Cruise 01/05, 11 Jul08 Aug 2005. Multibeam bathymetry and high resolution sidescan sonar surveys within the SEA7 area of the UK continental shelf. National Oceanography Centre Southampton Research \& Con- sultancy Report 07.50 pp.

Kenchington, R. A. \& Hutchings, P. 2012. Science, biodiversity and Australian management of marine ecosystems. Ocean \& Coastal Management 69, 194-99.

Kiriakoulakis, K., Freiwald, A., Fisher, E. \& Wolff, G. 2007. Organic matter quality and supply to deep-water coral/mound systems of the NW European Continental Margin. International Journal of Earth Sciences 96, 159-70.

Levin, L. A. 1991. Interaction between metazoans and large, aggluti- nating protozoans: implications for the community structure of deep-sea benthos. American Zoology 31, 886-900.

Levin, L. A. 1994. Paleoecology and Ecology of Xenophyophores. Palaios 9, 32-41

Levin, L. A., DeMaster, D. J., McCann, L. D. \& Thomas, C. L. 1986. Effect of giant protozoans (class:Xenophyophorea) on deep-sea- mount benthos. Marine Ecology Progress Series 29, 99-104.

Levin, L. A. \& Gooday, A. J. 1992. Possible roles for Xenophyo- phores in deep-sea carbon cycling. In G. T. Rowe, G. T. \& V. Pariente, V. (eds) Deep-Sea Food Chains and the Global Carbon Cycle , 93-104. Dordrecht: Kluwer Academic Publishers.

Levin, L. A. \& Thomas, C. L. 1988. The Ecology of Xenophyophores (Protista) on Eastern Pacific Seamounts. Deep-Sea Research Part I: Oceanographic Research Papers 35, 2003-27

Liaw, A. \& Wiener, M. 2002. Classification and Regression by RandomForest. $R$ news 2, 18-22.

Linnaeus, C. v. 1758. Systema Naturae, edition X, vol. 1 (Systema naturae per regna tria naturae, secundum classes, ordines, genera, species, cum characteribus, differentiis, synonymis, locis. Tomus I. Editio decima, reformata). Holmiae: Salvii. 824 pp.

Liu, C., Berry, P. M., Dawson, T. P. \& Pearson, R. G. 2005. Selecting thresholds of occurrence in the prediction of species distributions. Ecography 28,385-93.

Long, D., Kerry, H., Davies, J. \& Stewart, H. 2010. JNCC Offshore Natura survey of Anton Dohrn Seamount and East Rockall Bank Areas of Search. JNCC Report Series 437. Peterborough, UK: Joint Nature Conservancy Committee.

Manel, S., Dias, J., Buckton, S. \& Ormerod, S. 1999. Alternative methods for predicting species distribution: an illustration with Himalayan river birds. Journal of Applied Ecology 36, 734-47.

Marmion, M., Parviainen, M., Luoto, M., Heikkinen, R. K. \& Thuiller, W. 2009. Evaluation of consensus methods in predictive species distribution modelling. Diversity and Distributions 15, 59-69.

McBreen, F., Askew, N., Cameron, A., Connor, D., Ellwood, H. \& Carter, A. 2011. UK SeaMap 2010: Predictive Mapping of Seabed Habitats in UK Waters. JNCC Report 446. Peterborough, UK: Joint Nature Conservation Committee. 103 pp.

Miller, K. J., Rowden, A. A., Williams, A. \& Häussermann, V. 2011. Out of their depth? Isolated deep populations of the cosmopolitan coral Desmophyllum dianthus may be highly vulnerable to environmental change. PLOS ONE 6, e19004.

Mortensen, P. B., Hovland, T., Fossa, J. H. \& Furevik, D. M. 2001 Distribution, abundance and size of Lophelia pertusa coral reefs in mid-Norway in relation to seabed characteristics. Journal of the Marine Biological Association of the UK 81, 581-97.

Mortensen, P. B. \& Buhl-Mortensen, L. 2004. Distribution of deepwater gorgonian corals in relation to benthic habitat features in the Northeast Channel (Atlantic Canada). Marine Biology 144, 1223-38.

Mortensen, P. B. \& Buhl-Mortensen, L. 2005. Coral habitats in The
Gully, a submarine canyon off Atlantic Canada. In Freiwald, A. \& Roberts, J. M. (eds) Cold-Water Corals and Ecosystems, 24777. Berlin-Heidelberg: Springer-Verlag. 1244 pp.

Norse, E. A., Brooke, S., Cheung, W. W. L., Clark, M. R., Ekeland, I., Froese, R., Gjerde, K. M., Haedrich, R. L., Heppell, S. S., Morato, T., Morgan, L. E., Pauly, D., Sumaila, R. \& Watson, R. 2012. Sustainability of deep-sea fisheries. Marine Policy 36 307-20.

OSPAR. 2008. OSPAR List of Threatened and/or Declining Species and Habitats. OSPAR Agreement 2008-06, 1-4.

Phillips, S. J., Anderson, R. P. \& Schapire, R. E. 2006. Maximum entropy modeling of species geographic distributions. Ecological Modelling 190,231-59.

Phillips, S. J. \& Dudík, M. 2008. Modelling of Species Distributions with MaxEnt: New Extensions and a Comprehensive Evaluation. Ecography31,161-75.

Poulos, H. M., Chernoff, B., Fuller, P. L. \& Butman, D. 2012. Ensemble forecasting of potential habitat for three invasive fishes. Aquatic Invasions 7, 59-72.

Puig, P., Canals, M., Company, J. B., Martín, J., Amblas, D., Lastras, G., Palanques, A. \& Calafat, A. M. 2012. Ploughing the deep sea floor. Nature 489, 286-89.

R Development Core Team. 2011. R: A Language and Environment for Statistical Computing. Vienna, Austria: R Foundation for Statistical Computing.

Ready, J., Kaschner, K., South, A. B., Eastwood, P. D., Rees, T., Rius, J., Agbayani, E., Kullander, S. \& Froese, R. 2010. Predicting the distributions of marine organisms at the global scale. Ecological Modelling 221, 467-78.

Reiss, H., Cunze, S., Konig, K., Neumann, H. \& Kroncke, I. 2011. Species distribution modelling of marine benthos: a North Sea case study. Marine Ecology Progress Series 442, 71-86.

Rengstorf, A. M., Yesson, C., Brown, C. \& Grehan, A. J. 2013. Highresolution habitat suitability modelling can improve conservation of vulnerable marine ecosystems in the deep sea. Journal of Biogeography 40(9), 1702-14.

Rice, A., Thurston, M. \& New, A. 1990. Dense aggregations of a hexactinellid sponge Pheronema carpenteri in the Porcupine Seabight (northeast Atlantic Ocean), and possible causes. Progress in Oceanography 24, 179-96.

Rinehart, R., Wright, D., Lundblad, E., Larkin, E., Murphy, J., \& Cary-Kothera, L. 2004. ArcGIS 8.x benthic terrain modeler: Analysis in American Samoa. In Proceedings of the 24th Annual ESRI User Conference, San Diego, CA, Paper 1433.

Roberts, J. M., Harvey, S. M., Lamont, P. A., Gage, J. D. \& Humphery, J. D. 2000. Seabed photography, environmental assessment and evidence for deep-water trawling on the continental margin west of the Hebrides. Hydrobiologia 441, 173-83.

Roberts, J. M., Wheeler, A. J. \& Freiwald, A. 2006. Reefs of the deep the biology and geology of cold-water coral ecosystems. Science 312, 543-47.

Robinson, L. M., Elith, J., Hobday, A. J., Pearson, R. G., Kendall, B. E., Possingham, H. P. \& Richardson, A. J. 2011. Pushing the limits in marine species distribution modelling: lessons from the land present challenges and opportunities. Global Ecology and Biogeography 20, 789-802.

Rogers, A. D. 2000. The role of the oceanic oxygen minima in generating biodiversity in the deep sea. Deep-Sea Research Part II: Topical Studies in Oceanography 47, 119-48.

Rooper, C. N., Wilkins, M. E., Rose, C. S. \& Coon, C. 2011. Modeling the impacts of bottom trawling and the subsequent recovery rates of sponges and corals in the Aleutian Islands, Alaska. Continental Shelf Research 31, 1827-34.

Ross, R. E. \& Howell, K. L. 2013. Use of predictive habitat modelling to assess the distribution and extent of the current protection of 'listed' deep-sea habitats. Diversity and Distributions 19, 433-45.

Ruhl, H. A. \& Smith, K. L. 2004. Shifts in deep-sea community structure linked to climate and food supply. Science 305, 513-15.

Shires, R., Gooday, A. J. \& Jones, A. R. 1994. The Morphology and Ecology of an Abundant New Komokiacean Mudball (Komokiacea, Foraminiferida) from the Bathyal and Abyssal NE Atlantic. Journal of Foraminiferal Research 24, 214-25.

Smith, A. B., Santos, M. J., Koo, M. S., Rowe, K. C., Rowe, K. M. C., Patton, J. L., Beissinger, S. \& Moritz, C. 2013. Evaluation of species distribution models by resampling of sites surveyed a century ago by Joseph Grinnell. Ecography 36, 1017-31.

Stevens, T. \& Connolly, R. M. 2004. Testing the utility of abiotic surrogates for marine habitat mapping at scales relevant to management. Biological Conservation 119,351-62.

Stewart, H., Davies, J. S., Long, D., Strömberg, H. \& Hitchen, K. 2009. JNCC Offshore Natura Survey: Anton Dohrn Seamoun and East Rockall Bank. JNCC Cruise Report CR/09/113. Peterborough, UK: Joint Nature Conservation Committee.

Stohlgren, T. J., Ma, P., Kumar, S., Rocca, M., Morisette, J. T., Jarnevich, C. S. \& Benson, N. 2010. Ensemble habitat mapping of invasive plant species. Risk Analysis 30, 224-35. 
Strømgren, T. 1971. Vertical and horizontal distribution of Lophelia pertusa (Linné) in Trondheimsfjorden on the west coast of Norway. Kongelige Norske Videnskabelig Selskaps Skrifter 6, 1- 19.

Tendal, O. S. 1972. A monograph of the Xenophyophorea (Rhizopodea, Protozoa). Galathea Report 12, 7-103.

Tendal, O. S. 1979. Aspects of the biology of Komokiagea and Xeno- phyophorea. Sarsia 64, 13-17.

Tendal, O. S. 1996. Synoptic checklist and bibliography of the Xeno- phyophorea (Protista), with a zoogeographical survey of the group. Galathea Report 17, 79-101.

Thiem, O., Ravagnan, E., Fossa, J. H. \& Berntsen, J. 2006. Food supply mechanisms for cold-water corals along a continental shelf edge. Journal of Marine Systems 60, 207-19.

Tyler, P. \& Young, C. 1998. Temperature and pressure tolerances in dispersal stages of the genus Echinus (Echinodermata: Echinoidea): prerequisites for deep-sea invasion and speciation. Deep-Sea Re- search Part II: Topical Studies in Oceanography 45(1-3), 253-77.

UN General Assembly. 2003. Oceans and the Law of the Sea. Report of the Secretary General A/58/65.

Veloz, S. D. 2009. Spatially autocorrelated sampling falsely inflates measures of accuracy for presence-only niche models. Journal of Biogeography 36, 2290-99.

Ward, T., Vanderklift, M., Nicholls, A. \& Kenchington, R. 1999. Selecting marine reserves using habitats and species assemblages as surrogates for biological diversity. Ecological Applications 9, 691-98.

Weiss, A. D. 2011. Topographic Positions and Landforms Analysis. (Conference Poster, ESRI International Users Conference, San Diego, California).
Wheeler, A. J, Beyer, A., Freiwald, A., de Haas, H., Huvenne, V. A. I., Kozachenko, M., Olu-Le Roy, K. \& Opderbecke, J. 2007. Morphology and environment of cold-water coral carbonate mounds on the NW European margin. International Journal of Earth Sciences 96, 37-56.

White, M., Mohn, C., de Stigter, H. \& Mottram, G. 2005. Deep-water coral development as a function of hydrodynamics and surface productivity around the submarine banks of the Rockall Trough, NE Atlantic. In Friewald, A. \& Roberts, J. M. (eds) Cold-Water Corals and Ecosystems, 503-14. Berlin-Heidelberg: Springer. 1244 pp.

Williams, A., Bax N. J., Kloser R. J., Althaus F., Barker B. \& Keith G. 2009. Australia's deep-water reserve network: implications of false homogeneity for classifying abiotic surrogates of biodiversity. ICES Journal of Marine Science: Journal du Conseil 66, 214-24.

Williams, A., Schlacher, T. A., Rowden, A. A., Althaus, F., Clark, M. R., Bowden, D. A., Stewart, R., Bax, N. J., Consalvey, M. \& Kloser, R. J. 2010. Seamount megabenthic assemblages fail to recover from trawling impacts. Marine Ecology 31, 183-99.

Wilson, J. B. 1979. Patch Development of the Deep-Water Coral Lophelia pertusa (L) on Rockall Bank. Journal of the Marine Biological Association of the United Kingdom 59(1), 165-77.

Wisz, M. S., Hijmans, R. J., Li, J., Peterson, A. T., Graham, C. H., Guisan, A. \& NCEAS Predicting Species Distributions Working Group. 2008. Effects of sample size on the performance of species distribution models. Diversity and Distributions 14, 763-73.

Wright, D. J., Lundblad, E. R., Larkin, E. M., Rinehart, R. W., Murphy, J., Cary-Kothera, L. \& Draganov, K. 2005. ArcGIS benthic terrain modeler. Corvallis, Oregon: Oregon State University, Davey Jones Locker Seafloor Mapping/Marine GIS Laboratory and NOAA Coastal Services Center. 